\title{
Postharvest losses of fruits and vegetables in different microregions of Maranhão, Brazil
}

The fruits and vegetables sector is one of the most relevant activities in the Brazilian economy, but it is frequently affected by barriers, such as the expressive rate of postharvest losses. In Maranhão, studies about these indicators are scarce, although they could assist in the identification of risk factors, food distribution, and improvement in socioeconomic and environmentals aspects. This study aimed to carry out a socioeconomic survey of the marketing and post-harvest losses of fruit and vegetables in the main retail markets of seven cities in Maranhão. For six months, direct interviews in 107 commercial establishments, were performed. The results indicated that more than $96 \%$ of fruits and vegetables come from Piaui, Bahia, and Ceará, transported in open trucks, without refrigeration, and on paved roads. Among fruits, papaya (17.90\%), avocado $(16.55 \%)$, and guava $(13.82 \%)$ stand out as those which commonly present a higher loss rate, while for vegetables were eggplant (24.70\%), potatoes (15.98\%), and cucumber (15.69\%). Furthermore, Physiological disorders and mechanical damage were considered as the major causes leading to the losses. Comparing among the cities, Santa Quitéria and São Bernardo are the ones that showed elevated losses rates. Therefore, it is necessary to stimulate the production of fruits and vegetables in Maranhão, as well as to provide better training in commercial management and good postharvest practices to increase the profitability of this activity and reduce environmental impacts.

Keywords: Environment; Good Practices; Management; Physiological Disorders; Training.

\section{Perdas pós-colheita de frutas e vegetais em diferentes microrregiões do Maranhão, Brasil}

O setor de frutas e hortaliças é uma das atividades mais relevantes da economia brasileira, mas é freqüentemente afetado por barreiras, como os índice expressivos de perdas pós-colheita. No Maranhão, os estudos sobre esses indicadores são escassos, embora possam auxiliar na identificação de fatores de risco, distribuição de alimentos e melhoria nos aspectos socioeconômicos e ambientais. O presente estudo teve como objetivo realizar um levantamento socioeconômico das perdas mercadológicas e pós-colheita de frutas e hortaliças nos principais mercados varejistas de sete cidades maranhenses. Durante seis meses, foram realizadas entrevistas diretas em 107 estabelecimentos comerciais. Os resultados indicaram que mais de 96\% das frutas e hortaliças vêm do Piauí, Bahia e Ceará, transportadas em caminhões abertos, sem refrigeração e em estradas asfaltadas. Dentre as frutas, mamão (17,90\%), abacate (16,55\%) e goiaba (13,82\%) destacamse como as que comumente apresentam maior índice de perdas, enquanto nas hortaliças foram berinjela (24,70\%), batata (15,98\%) e pepino (15,69\%). Além disso, distúrbios fisiológicos e danos mecânicos foram considerados as principais causas dos prejuízos. Na comparação entre as cidades, Santa Quitéria e São Bernardo são as que apresentaram elevados índices de perdas. Portanto, é necessário estimular a produção de frutas e hortaliças no Maranhão, bem como proporcionar melhor capacitação em gestão comercial e boas práticas de pós-colheita para aumentar a rentabilidade dessa atividade e reduzir os impactos ambientais.

Palavras-chave: Meio Ambiente; Boas práticas; Gestão; Distúrbios fisiológicos; Treinamento.

Topic: Planejamento, Gestão e Políticas Públicas Ambientais

Reviewed anonymously in the process of blind peer
Received: 07/08/2020

Approved: 26/09/2020
Lusiane de Sousa Ferreira (iD) Universidade Federal do Espírito Santo, Brasil

http://lattes.cnpq.br/2873060128693838 http://orcid.org/0000-0001-6625-3965 lusianesf@hotmail.com

Antonio Gabriel da Costa Ferreira (iD Universidade Federal do Maranhão, Brasil http://lattes.cnpq.br/8950526022963441 http://orcid.org/0000-0003-0931-0120 agcf09@gmail.com

\section{Deucleiton Jardim Amorim (iD}

Universidade Estadual de São Paulo, Brasil http://lattes.cnpq.br/3121121800829042 http://orcid.org/0000-0002-6789-0760 deucleitonamorim@hotmail.com
Marcelo de Sousa da Silva (iD Universidade Federal do Maranhão, Brasi http://lattes.cnpq.br/5929903987543113 http://orcid.org/0000-0002-6074-8761 marcelosousamj@hotmail.com

uana Ribeiro Silva (iD)

Universidade Federal do Maranhão, Brasi http://lattes.cnpq.br/4347815856873120 http://orcid.org/0000-0002-9171-613X luannaccb1992@hotmail.com

Edmilson Igor Bernardo Almeida Universidade Federal do Maranhão, Brasil http://lattes.cnpq.br/4485991332506597 http://orcid.org/0000-0003-2051-7085 edmilsoni@hotmail.com

\section{José Roberto Brito Freitas (1D) \\ Universidade Federal do Maranhão, Brasil http://lattes.cnpq.br/5427491615270649 http://orcid.org/0000-0003-0513-4211 joserobertobritofreitas@yahoo.com.br \\ Washington da Silva Sousa (iD) \\ Universidade Federal do Maranhão, Brasil http://lattes.cnpq.br/3325519024009786 http://orcid.org/0000-0002-6563-6814 wssousa@gmail.com \\ Ricardo Alves de Araújo \\ Universidade Estadual do Maranhão, Brasil http://lattes.cnpq.br/6876885944020553 http://orcid.org/0000-0001-9696-5680 ricardo_zoo@hotmail.com}

Leonardo Bernardes Taverny de Oliveira (iD) Universidade Federal do Maranhão, Brasil http://lattes.cnpq.br/5822293050229432 http://orcid.org/0000-0002-2971-2066 tavernyzoot@yahoo.com.br

\section{Referencing this:}

FERREIRA, L. S.; FERREIRA, A. G. C.; AMORIM, D. J.; SILVA, M. S.; SILVA, L. R.; ALMEIDA, E. I. B.; FREITAS, J. R. B.; SOUSA, W. S.; ARAÚJO, R. A.; OLIVEIRA, L. B. T.. Postharvest losses of fruits and vegetables in different microregions of Maranhão, Brazil. Revista Ibero Americana de Ciências Ambientais, v.11, n.5, p.624-637, 2020. DOI: http://doi.org/10.6008/CBPC2179-6858.2020.005.0056 


\section{INTRODUCTION}

The global scene of fruits and vegetables production stands out for encompassing a diversity of cultivated species, whose consumption potential has provided continuous progress in recent years. Nowadays, fruit crops are considered one of the most significant segments in the Brazilian agricultural environment, with a $25 \%$ share of national agricultural production, covering 2.6 million hectares and generating 6.0 million direct jobs. While, vegetable crops occupy an area of 2.7 million hectares, generates about 7 million direct jobs and approximately 20 million indirect jobs (ABF, 2017; ABH, 2018).

Despite the socioeconomic expressiveness and food importance, the losses rates occurring along the fruits and vegetable production chain are significantly high in Brazil, since it varies between 35 and $40 \%$. While in developed countries, such as the United States, which invests in handling and conservation technology in different postharvest stages, so, the values do not exceed 10\% (RIBEIRO et al., 2011; BARBOSA et al., 2012).

Postharvest losses cause a series of damages, from the field to the final consumer, and vary mainly according to the geographic region, technological level employed and level of training of those involved (SOARES et al., 2018). Generally, postharvest losses are the result of inappropriate handling and or inadequate temperature management during packaging and storage. Thus, it is evident the importance of characterizing and quantifying them in each link of the production chain, for possible verification of the need to adopt adequate control measures (ANTUNES et al., 2017).

Although Maranhão has one of the largest Brazilian territorial extensions and favorable conditions for growing vegetable crops, its production is still at the beginning, which leads to the constant traffic of products from other Brazilian states. Moreover, the increased path taken can impact on the postharvest losses indicators, prices practiced, and the final quality of the product (TOMM et al., 2018; SILVA et al., 2018). Guerra et al. (2017) emphasized that there is a need for public policies and financial incentives that help to reduce losses and damages during the process of selling fruits and vegetables in Brazil.

Thus, this study aimed to carry out a socio-economic survey and postharvest losses of fruits and vegetables in the main retail chains of seven cities, in different microregions, at the Maranhão state.

\section{MATERIALS AND METHODS}

The survey was conducted from November 2018 to April 2019, in the cities of Dom Pedro (-4 $28^{\prime} 60^{\prime \prime}$ S, $-44^{\circ} 27^{\prime} 0^{\prime \prime}$ W), Fortuna $\left(-5^{\circ} 43^{\prime} 22^{\prime \prime}\right.$ S, $-44^{\circ} 9^{\prime} 30^{\prime \prime}$ W), Presidente Dutra $\left(-5^{\circ} 17^{\prime} 25^{\prime \prime}\right.$ S, $-44^{\circ} 29^{\prime} 23^{\prime \prime}$ W), São

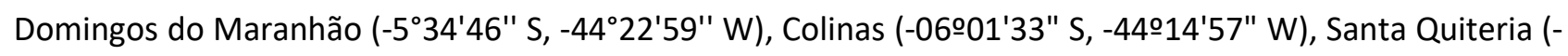
$\left.3^{\circ} 29^{\prime} 59^{\prime \prime} \mathrm{S},-42^{\circ} 33^{\prime} 54^{\prime \prime} \mathrm{W}\right)$, and São Bernardo (-349'18” S, -3930'34” W), which comprise the microregions of Presidente Dutra, Chapadas do Alto Itapecuru and Baixo Parnaíba Maranhense. Data were collected through direct interviews with those responsible for fruits and vegetable marketing in each municipality, totaling 107 commercial establishments visited. These include street markets/fairs, greengrocers, and supermarkets. 
Thus, a questionnaire was proposed according to Almeida et al. (2012), composed of objective questions that covered the following information: socioeconomic aspects (education, professional activity, monthly income from the vegetable sale, technical knowledge, and training); handling (labor skills), runoff (product origin, transport type, road infrastructure); packaging (packaging type and product standardization); storage (exposure time and technologies adopted); commercialization (volume offered, establishment and countertops cleanliness, standardized products on the shelves, adopted prices, and trade seasonality); and postharvest losses (volumes offered and lost, and causes of the losses).

Through this information, it was possible to define a scenario of fruits and vegetable commercialization and to elaborate a diagnosis of the postharvest losses occurring in the cities studied. Regarding the monthly income from the sale of produce, it was based on minimum wages, which at the time of the study was quoted at $\mathrm{R} \$ 954.00$. The origin of postharvest losses was defined according to Chitarra et al. (2005), in mechanical damage, physiological disorders, and phytopathological injuries. The estimate of relative losses, in percentage, was estimated by the following formula: Losses $(\%)=\{[(\mathrm{VO}-\mathrm{VV}) / \mathrm{VO}] \times 100\}$

In which, VO refers to the mean quantity of fruits and vegetables offered per week $\left(\mathrm{kg} \mathrm{week}^{-1}\right)$. VV represents the mean quantity of fruit and vegetables sold per week $\left(\mathrm{kg} \mathrm{week}^{-1}\right)$. These relative losses were classified as low (less than or equal to 5\%), medium (between 5.1 and 10.0\%), and high (greater than or equal to $10.01 \%)$, as proposed by Tofanelli et al. (2009).

Estimates of relative losses of all fruits and vegetables marketed allowed to estimate total losses, in kilograms, on the volume offered per week. This allowed a significant highlight to the volume lost for each fruits and vegetables, according to its importance in consumption and consequently on offer into commercial establishments. To get a more detailed study, the fruits were classified as climacteric and non-climacteric, while vegetables were classified as vegetables-fruit, underground vegetables, and leafy vegetables.

Traders pointed out through objective questions the main causes of injury for each fruits and vegetable. Through results quantification, it was possible to obtain the mean percentage of causal agents for each fruits and vegetables, with subsequent calculation of the relative percentage of interference on the total percentage of postharvest losses.

Data were analyzed by descriptive statistics and presented in graphs and tables, according to the type of variable analyzed. Losses were expressed in percentage (\%) and in kilograms per week ( $\mathrm{kg} \mathrm{week}^{-1}$ ), presented in tables, in which the mean loss of each fruit was associated with the relative percentage of the causal factor. Therefore, postharvest losses received the name of physiological, mechanical, and phytopathological losses.

Regarding the mean loss percentage, for each fruits and vegetables, the standard error of the mean and variation coefficient was estimated, to define the experimental precision. The volume of fruits and vegetables offered was estimated as the quotient of the amount offered, in kilograms per week, of each fruits and vegetables, by the analyzed sample space (107 commercial establishments). To provide a more solid basis for the present study, losses were estimated for each municipality, with their respective insertion 
microregions and population.

\section{RESULTS AND DISCUSSION}

Regarding the educational level, it was found that $35.51 \%$ had completed high school, while $23.36 \%$ incomplete high school, $12.14 \%$ completed elementary school, $8.41 \%$ incomplete elementary school, $9.84 \%$ are illiterate, and. Only $4.67 \%$ had completed higher education, while $6.54 \%$ did not complete higher education (Figure 1A).

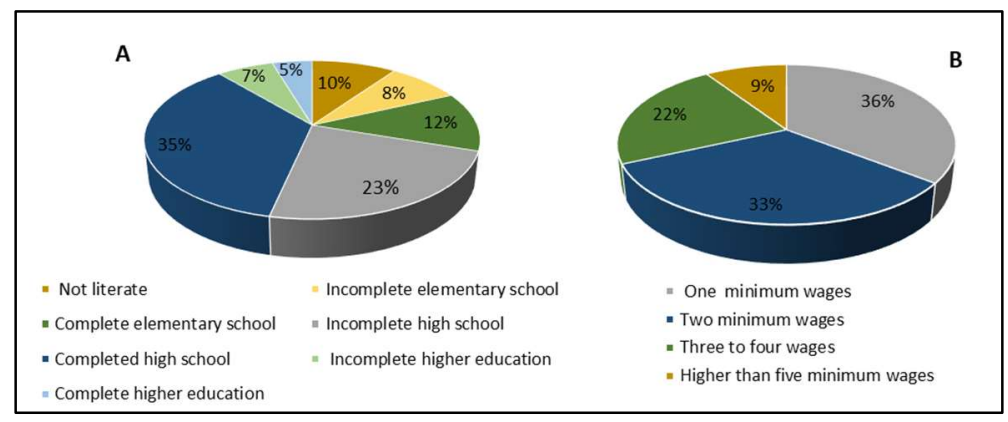

Figure 1: Education level $(A)$ and monthly income $(B)$ of retailers obtained from the sale of fruits and vegetables in differents microregions of Maranhão.

These results corroborate those found by Amor et al. (2012) and Tomm et al. (2018). They found that most traders had elementary and high school education. According to these authors, this may limit the implementation of improvements in technical and technological aspects in commercial establishments.

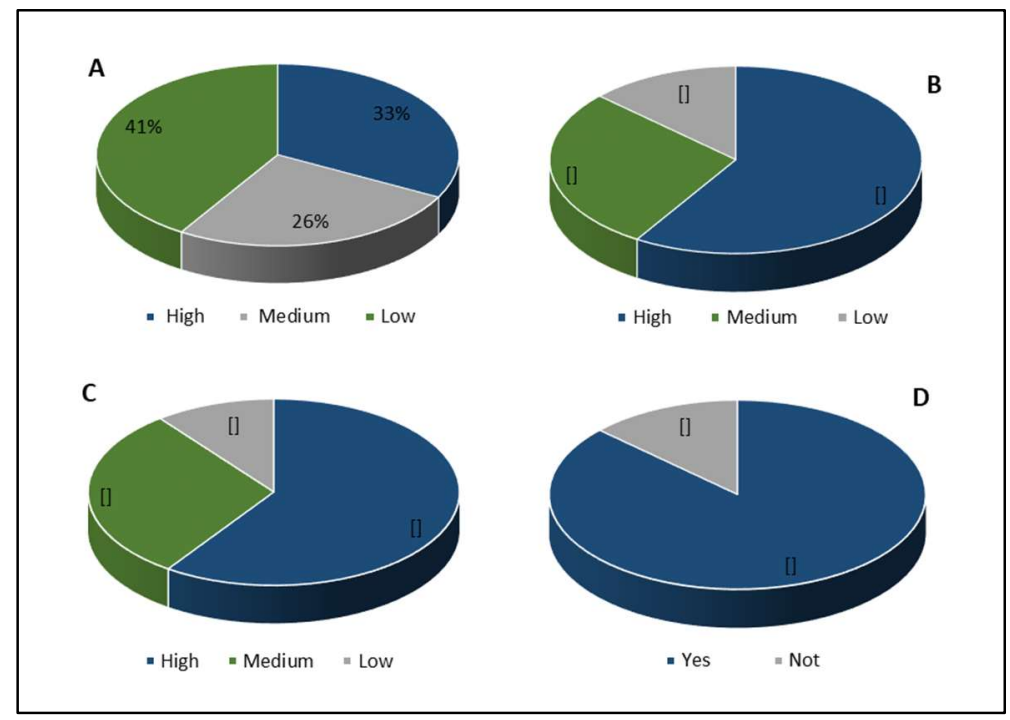

Figure 2: Technical knowledge levels of those responsible for the fruits and vegetables retail sectors on production (A), marketing (B), management (C), and interest in technical training (D).

The income generated from the sale of vegetables is between one and five minimum wages, a fact that expresses the relevance of the activity as an employment and income source in the cities object of this study. In general, $68.22 \%$ earned one to two minimum wages, $22.42 \%$ three to four wages, and $9.34 \%$ higher than five minimum wages (Figure 1B). These results differ from those found by Silva et al. (2018), who estimated that around $90 \%$ of fruits and vegetables traders in the microregion of Chapadinha, obtained a 
monthly income of up to one minimum wage, only. Concerning the technical knowledge level of fruits and vegetables production, $41.12 \%$ reported having a low level, while $32.72 \%$ has a high level, and only $26.16 \%$ had medium technical knowledge (Figure 2A).

Assessing commercialization and management, the majority of traders $(58.87 \%$ and $59.60 \%$, respectively) declared that they had a high technical knowledge level (Figure 2B and 2C). Moreover, they stated that a long time in the commercial sector allowed them to acquire experiences about the daily challenges of the activity, although not all provide time for training. Among the interviewees, $86.92 \%$ reported interest in technical training (Figure 2D), while the remaining $13.01 \%$ declared they had no interest due to the unfeasibility of adopting technologies. It can be inferred, based on these results, the lack of perception about basic aspects that can be corrected without cost.

Regarding the origin of fruits and vegetables, it was found that $96.26 \%$ are from other states, especially Piauí, Bahia, and Ceará. The rest are from Brejo (MA) and neighboring cities (Figure 3A). These results corroborate with Tomm et al. (2018), Silva et al. (2018) and Ferreira et al. (2020), who emphasized that around $90 \%$ of fruits and vegetables marketed in seven cities in the East Mesorregion of Maranhão come from these states.

Therefore, it is understood that there is a high potential for the fruits and or vegetable exploitation growing in the Maranhão state. Besides, it is emphasized that quality, prices, and losses resulting from postharvest losses are possibly affected by the origin of the fruits and vegetables since they are transported for long distances until their final destination. Thus, leading to relevant socioeconomic impacts, especially when commercial profitability is low.

Trucks predominated as the commonly used mode of transport for fruits and vegetables carrying (Figure 3B); in most cases, with open load (without canvas) or covered with canvas. In rare situations, refrigerated trunk vehicles are used, which according to Dias (2012), might reduce quality and increases the risks of postharvest losses of perishable products, such as fruits and vegetables, especially over long distances (Figure 3E).

Runoff was carried out by paved roads; however, according to the traders, there were inadequate traffic conditions, especially in some Maranhão perimeters. In agreement with Carvalho et al. (2015), the conditions of poor conservation of runways, directly contribute to the increase of postharvest losses, given the prolongation of the journey time and a higher occurrence of physiological, mechanical, and phytopathological disorders.

Fruits and vegetables were predominantly stocked during the interval of one to seven days (Figure 3C). However, there were cases where stock replenishment was carried out two to three times a week, which could help to reduce losses because the conditions were generally insufficient to package large quantities of products. In this aspect, it was seen that only $15 \%$ of traders adopted refrigerated storage. Of these, $7 \%$ were packaged in refrigerators and $8 \%$ in freezers, which may also culminate in physiological disorders, as these technologies are not suitable for regulating temperature and relative humidity. 


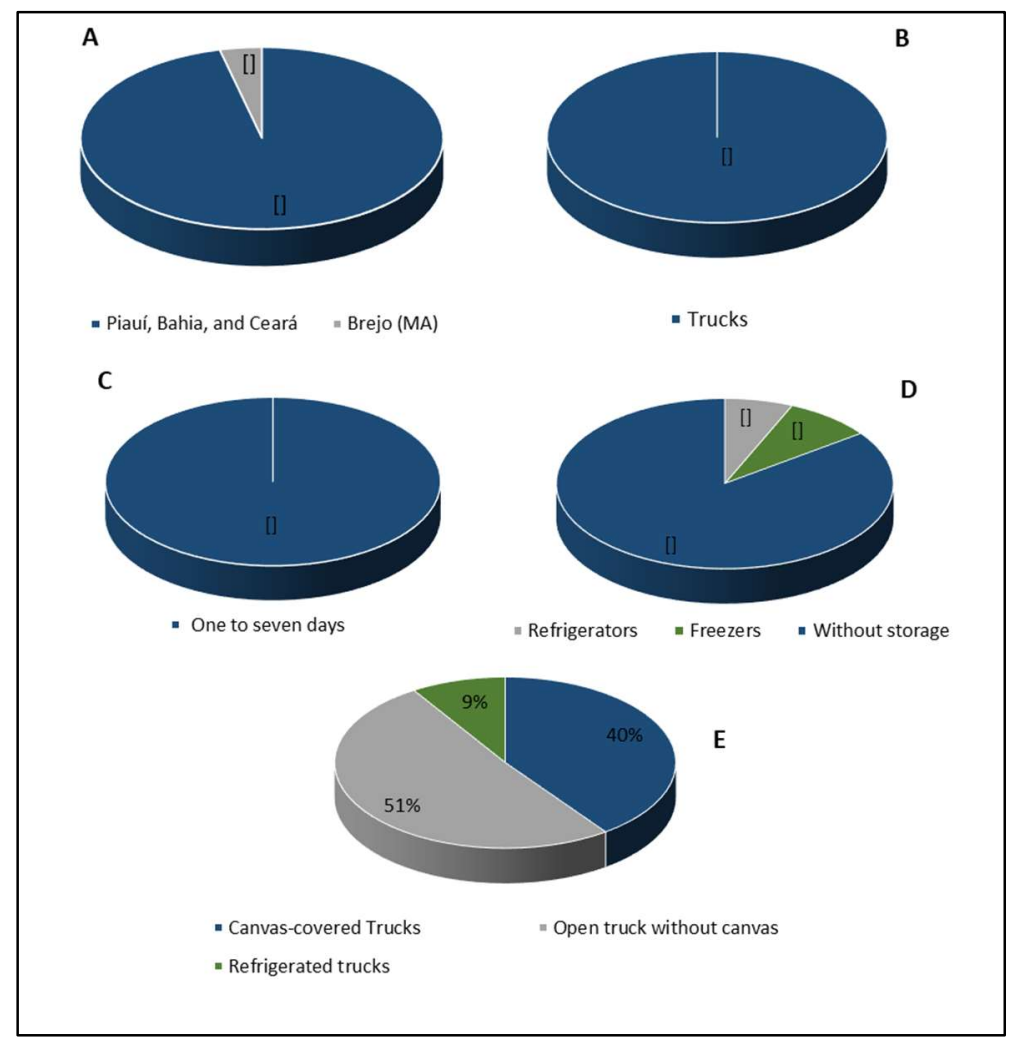

Figure 3: Products Origin (A), transport (B), storage period (C), storage (D) and trucks typ=e most used for fruits and vegetables $(E)$ in differents microregions of Maranhão.

According to Barreto et al. (2016), refrigerated storage can provide an increase in the useful life of fresh produce by regulating temperature and humidity, to acceptable ranges, in order to reduce respiration and ethylene synthesis, especially in climatic products. Moreover, Aghdam et al. (2014) pointed out that in freezers and refrigerators, excessive cold and dry air must cause injuries called chilling, very common in fruits such as avocado and bananas; or breaking dormancy, as in onion and potato. However, Neves (2016) emphasize that some fruits, such as temperate ones, may be less sensitive to cold and, therefore, benefit from the technologies mostly adopted by traders.

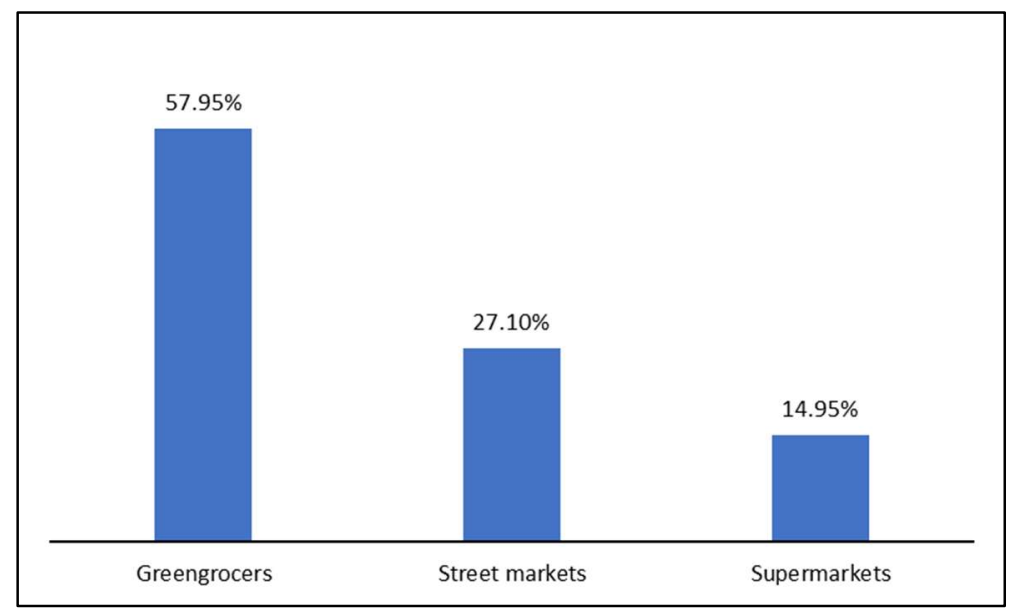

Figure 4: Participation of the commercial segments of fruits and vegetables in differents microregions of Maranhão.

Fruits and vegetables were commercialized in several segments, particularly in street markets/fairs, 
greengrocers, and supermarkets (Figure 4). In the present study, the sample space was made up of 107 fruits and vegetable retail markets, $58 \%$ of which were greengrocers, $27 \%$ street markets, and $15 \%$ supermarkets.

According to Lermen (2017), the consumer's choice in different segments depends on factors such as product quality, cleanliness, and hygiene of the place, proximity to the residence, price, satisfactory service, among others. Tomm et al. (2018) found that in the Chapadinha microregion, greengrocers (77\%), street markets $(15 \%)$, supermarkets $(5 \%)$ and grocery stores $(3 \%)$ highlighted as the main fruits and vegetables retailers.

Furthermore, Amorim et al. (2017) reported that vegetables show differences in quality for different market segments, emphasizing green vegetables, which according to the authors, had better price and quality in the city of Chapadinha (MA). Which demonstrates the fact that this is a segment that has great influence and high demand by consumers in different cities in Maranhão state.

Relevant diversity of fruits was offered in different retail segments, mainly bananas, apples, papayas, watermelons, passion fruit, and pineapples, which were found in all the establishments visited. Mango, guava, melon, and avocado were sold in up to $90 \%$ of the establishments, while the grape was present in 69\% (Figure 5).

The establishments also presented a wide diversity of vegetables offered, such as underground, fruit and leafy vegetables. Potatoes, tomatoes, carrots, cucumbers, peppers and lettuce are marketed in all the environments assessed, while sweet potatoes had an 88\% share and eggplant, 64\% (Figure 6).

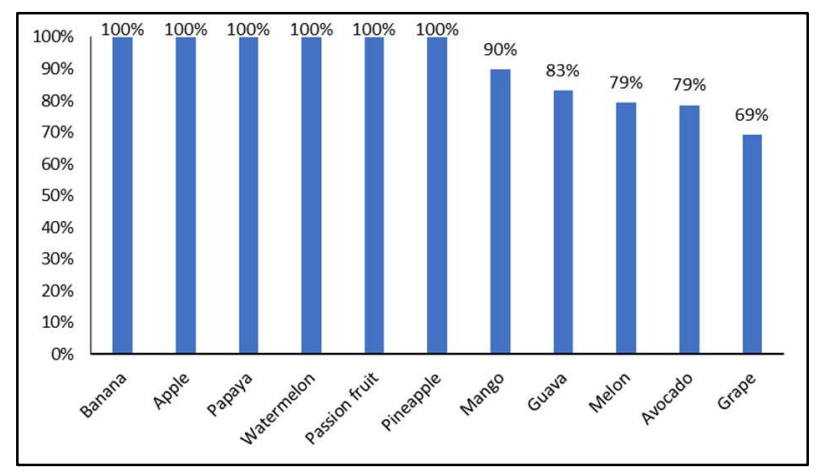

Figure 5: Frequency of the main fruits offered in the differents microregions of Maranhão.

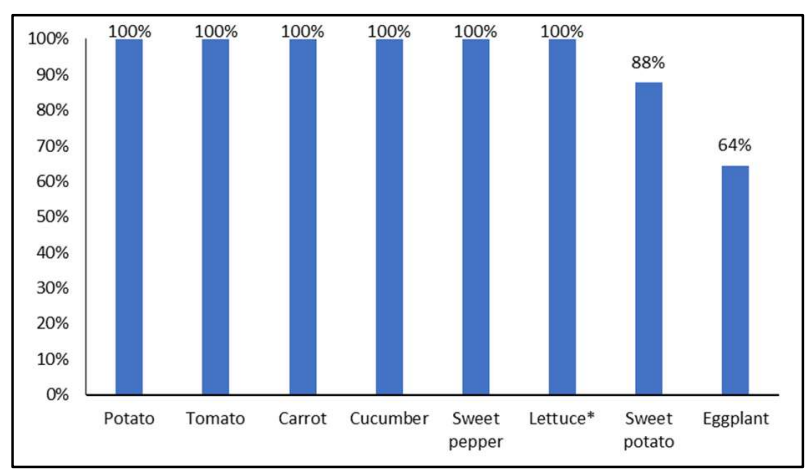

Figure 6: Frequency of the main vegetables offered in differents microregions of Maranhão.

The frequency with which these products are made available in establishments is closely related to the population's eating habits. Although, there are cases that lack adequate control concerning the volume offered given the demand for some of these vegetables, which leads to postharvest losses. This corroborates with Silva (2018), who associated the diversity and volume of products offered to the cultural habits of different locations, as well as to certain times of the year.

Data contained in Table 1 show the percentage of postharvest losses of fruit, estimated in the retail sector of seven cities in Maranhão. The following decreasing order of losses was obtained: papaya (17.90\%) $>$ avocado $(16.55 \%)>$ guava $(13.82 \%)>$ grape $(9.80 \%)>$ passion fruit $(8.90 \%)>$ mango $(7.80 \%)>$ banana $(7.60 \%)>$ watermelon $(5.20 \%)>$ pineapple $(5.08 \%)>$ apple $(5.00 \%)>$ melon $(4.20 \%)$. 
Table 1: Postharvest fruit losses recorded in the retail market in differents microregions of Maranhão.

\begin{tabular}{lllllllll}
\hline \multirow{3}{*}{ Classification } & & & & & \multicolumn{2}{c}{ Cause of losses (\%) } \\
\cline { 5 - 9 } & Fruits & MVO & TAL & RL $\pm \mathbf{e}$ & CV & PL & ML & PPL \\
\hline & Papaya & 27.14 & 4.85 & $17.90 \pm 0.86$ & 12.00 & 10.03 & 6.70 & 1.17 \\
& Avocado & 41.42 & 6.85 & $16.55 \pm 1.37$ & 13.57 & 928 & 6.18 & 1.09 \\
& Guava & 13.42 & 1.85 & $13.82 \pm 0.61$ & 22.00 & 8.26 & 4.02 & 1.54 \\
& Passion fruit & 36.85 & 3.28 & $8.90 \pm 1.10$ & 22.00 & 6.25 & 1,66 & 0.99 \\
& Mango & 62.57 & 4.85 & $7.80 \pm 0.86$ & 12.00 & 4.73 & 2.19 & 0.88 \\
& Banana & 254.28 & 19.32 & $7.60 \pm 2.56$ & 8.98 & 3.56 & 3.55 & 0.49 \\
& Watermelon & 191.42 & 9.95 & $5.21 \pm 1.74$ & 11.84 & 1.07 & 3.41 & 0.73 \\
& Apple & 54.71 & 2.73 & $5.00 \pm 0.69$ & 17.26 & 1.96 & 1.68 & 1.36 \\
& Melon & 23.85 & 1.00 & $4.20 \pm 0.31$ & 24.00 & 2.94 & 0.79 & 0.47 \\
\hline \multirow{2}{*}{ Non-climacteric } & Grape & 16.00 & 1.56 & $9.80 \pm 0.48$ & 21.00 & 6.41 & 2.28 & 1.09 \\
& Pineapple & 42.14 & 2.14 & $5.08 \pm 0.42$ & 13.00 & 1.66 & 3.09 & 0.33 \\
\hline
\end{tabular}

MVO: Mean volume offered (kg week ${ }^{-1}$ ); TAL: Total average loss (kg); RL: Relative loss (\%); PL: Physiological loss (\%); ML: Mechanical loss (\%); PPL: Phytopathological loss (\%); e: Mean standard error (\%); CV: Coefficient of variation (\%).

Among the relative losses of climacteric fruits, the values obtained for papaya (17.90\%), avocado (16.55\%), and guava (13.82\%), according to the classification proposed by Tofanelli et al. (2009), were classified as high losses. However, these fruits are not included among the greatest volumes offered, probably because they have certain morpho-physiological traits, such as high-water content, high respiratory rate, and also thin epidermis. This may have been intensified by ineffective postharvest practices during transportation, handling, and marketing, as reported by Nascimento et al. (2019)

The estimated results for passion fruit (8.90\%), mango (7.80\%), banana $(7.60 \%)$, and a watermelon (5.21\%) can be classified as average losses. However, it is worth mentioning that these fruits had a major volume offered, which could originate higher losses than those obtained for papaya, which losses were more expressive if compared to the volume offered per week, which was low. Losses for apples and melons were equivalent to $5.0 \%$, and $4.2 \%$, respectively. They were classified as low order, mainly associated with the balance between supply and demand.

Regarding relative losses of non-climacteric fruits, grape had $9.80 \%$ and pineapple $5.08 \%$, being classified as medium losses. According to Oliveira et al. (2015), unlike climatic fruits such as papaya, avocado and guava, which have increased respiration and ethylene synthesis in the ripening phase, grapes and pineapples have low metabolic activity after harvest, which can culminate in longer shelf life when stored under suitable conditions.

Despite the indices found in this study, the loss estimates for climacteric fruits can be designated as alarming, considering that the volumes offered were few and demonstrate the inability of the retail sector to conserve them. This fact may be related to the planning of the volume offered, as highlighted by Sousa et al. (2018) in their studies. These results are in line with Tomm et al. (2016) and Cia et al. (2010), who emphasized the importance of refrigeration for the storage of seasoned fruits, such as grapes, during their commercialization.

In general, it was found that the main causal factors for postharvest losses in climacteric and nonclimacteric fruits were physiological disorders, which ranged from 1.07 (watermelon) to $10.03 \%$ (papaya); 
besides, in some fruits, such as passion fruit, physiological losses represented up to $70.22 \%$ of the relative loss. These results corroborate with Campos et al. (2015), who conducted a diagnosis of postharvest losses of passion fruit in the retail market of Palmas (TO).

The main physiological disorders reported in this study were early ripening, rapid pulp softening, skin peeling, fresh weight loss, and color changes. It is assumed that these physiological disorders were possibly caused by adverse conditions of temperature and relative humidity, as well as the adoption of inappropriate practices during handling, transportation, packaging, and marketing, predisposing the fruits to rapid senescence and consequently, a consumption rejection.

Moreover, according to Vieites (2012), the temperature is one of the main factors that influence the control of breathing and sweating, aside from the speed at which microbial deterioration and physiological disorders occur during the storage period. As stated by Melo (2013), the variation in temperature can increase the speed of maturation and change the color of the skin, while the relative humidity influences weight loss and favors the incidence of fungi, which restricts acceptance by consumers.

Besides, the high prices practiced, for some fruits, can increase the time of commercialization, and consequently, the susceptibility to postharvest losses, especially the physiological ones. The magnitude for this type of loss may be related to poorly planning of the volume offered because the longer the shelf life, the greater the losses possibility. According to Goto (2010), around $70 \%$ of the decision to buy fruits and vegetables is based on its external appearance. Therefore, the trader needs to avoid fruits that are not in good condition for commercialization, which may also be an inoculum of diseases for healthy fruits.

Regarding mechanical damage, the estimative of postharvest losses associated with this factor varied from 0.79 (melon) to $6.70 \%$ (papaya). Among the fruits analyzed, the one that suffered the highest estimate of mechanical losses was watermelon, whose effects expressed $65.45 \%$ of its total losses. According to Tomm et al. (2018), during transportation or marketing, the inadequate fruits organization, without maturation patterns, fresh dough, and length may lead to higher risks of compressions, friction, abrasions, and cuts in fruits, like watermelons, which are shipped in bulk. In relation to vegetables, the decreasing order was: eggplant $(24.7 \%)>$ potato $(15.98 \%)>$ cucumber $(15.69 \%)>$ sweet potato $(14.0 \%)>$ sweet pepper $(11.28 \%)>$ carrot $(11.27 \%)>$ lettuce $(9.0 \%)>$ tomato $(7.46 \%)$ (Table 2$)$.

Table 2: Postharvest losses of vegetables recorded in the retail market in differents microregions of Maranhão.

\begin{tabular}{|c|c|c|c|c|c|c|c|c|}
\hline \multirow[b]{2}{*}{ Classification } & \multirow[b]{2}{*}{ Vegetable Crops } & \multirow[b]{2}{*}{ MVo } & \multirow[b]{2}{*}{ TAL } & \multirow[b]{2}{*}{$R L \pm e$} & \multirow[b]{2}{*}{ CV } & \multicolumn{3}{|c|}{ Cause of losses (\%) } \\
\hline & & & & & & PL & ML & PPL \\
\hline \multirow{4}{*}{ Fruits } & Eggplant & 13.28 & 3.28 & $24.70 \pm 0.69$ & 14.00 & 12.56 & 9.22 & 2.92 \\
\hline & Cucumber & 31.85 & 5.01 & $15.70 \pm 0.62$ & 9.00 & 10.12 & 2.93 & 2.64 \\
\hline & Sweet pepper & 46.85 & 5.28 & $11.28 \pm 1.54$ & 19.82 & 6.33 & 3.90 & 1.05 \\
\hline & Tomato & 182.1 & 13.57 & $7.46 \pm 1.45$ & 7.25 & 4.32 & 1.74 & 1.40 \\
\hline \multirow{3}{*}{ Underground } & Potato & 61.14 & 9.71 & $16.00 \pm 2.06$ & 14.00 & 7.62 & 7.32 & 1.04 \\
\hline & Sweet potato & 34.42 & 4.85 & $14.00 \pm 118$ & 16.50 & 6.02 & 6.93 & 1.05 \\
\hline & Carrot & 68.42 & 7.71 & $11.27 \pm 1.74$ & 15.00 & 5.69 & 4.74 & 0.84 \\
\hline Leafy & Lettuce & 31.14 & 2.85 & $9.00 \pm 0.96$ & 9.70 & 5.89 & 2.19 & 0.92 \\
\hline
\end{tabular}

MVO: Mean volume offered (kg week ${ }^{-1}$ ); TAL: Total average loss (kg); RL: Relative loss (\%); PL: Physiological loss (\%); ML: Mechanical loss (\%); PPL: Phytopathological loss (\%); e: Mean standard error (\%); CV: Coefficient of variation (\%). 
Among the vegetables-fruit, eggplant, cucumber, and pepper showed high losses, estimated at 24.70, 15.70 , and $11.28 \%$, respectively. The estimate for eggplant is worrying, since the volume offered was not pretty meaningful. According to Barbosa et al. (2012), maintenance of quality attributes and acceptance of eggplant by consumers is compromised by way of marketing, because the most establishments sell in bulk, in the absence of a refrigeration system.

Besides, Costa et al. (2015) emphasized that eating habits can interfere with the demand and consequent postharvest losses, resulting from the extension of the exposure time for sale. Thus, although the eggplants are marketed in only $64 \%$ of establishments assessed and present a low mean volume offered $(13.28 \mathrm{~kg})$, it is necessary to make improvements in the planning of quantity offered and also on conservation technologies.

Tomatoes and peppers have relatively similar morphological characteristics, physiological patterns change, and estimates of losses. In this regard, it is understood that more effective conservation practices could be adopted for these two vegetables, given their importance in food frequency, high perishability, and expressive volumes offered.

According to Canella et al. (2018), peppers and tomatoes are among the ten vegetables consumed in Brazil, which can accommodate traders in the insertion of improvements for their conservation, as the sales flow is fast. Nevertheless, the authors stressed that these are highly perishable vegetables with great potential for losses. Especially in the case of tomatoes that had a higher offer volume $(14,6$, and $4 \mathrm{~kg})$ than eggplants, cucumbers, and peppers, respectively.

Aware of the difficulties of merchants in investing in improvements in the conservation of perishable vegetables, some free or low-cost solutions could be implemented, such as adequate supply management, establishment hygiene, disposal of sick products, and use of packaging, for example. Evaluating the edible biofilm use in the green peppers postharvest conservation, Sena et al. (2016) achieved an improvement in the quality attributes of coated fruits. Freitas Junior (2019) and Silva (2019) obtained excellent results with the use of hermetic-bag in guava and tomato, respectively.

Among the studied underground vegetables, all showed high rates of post-harvest losses, whose estimates were 16,14 , and $11.27 \%$ for potatoes, sweet potatoes, and carrots, respectively. In a study conducted by Sousa et al. (2018), in Chapadinha (MA) retail market, they also found high losses to underground vegetables and pointed out physiological disorders as the principal cause. However, both results were lower than those found by Castro (2013), in Guanhães (MG), whose estimates reached up to 41.99\%. Thus, they emphasize the importance of improvements in the conservation of this group of vegetables.

Packaging used to transport these vegetables likely favored the increase in the incidence of mechanical, physiological, and phytopathological injuries, given that, normally, the packaging is made in stacked nylon bags or bulk. About leafy vegetables, the relative loss of lettuce was estimated at $9.0 \%$, whose physiological disorders represented $65.44 \%$ of this value. Although it is widely consumed and marketed, 
lettuce has high water content, which made it very perishable. This possibly culminated in losses classified as medium/median, mainly associated with their withering and darkening that make acceptance for purchase unfeasible.

According to Cassetari (2015), lettuce contains around 96\% water, and to preserve its characteristics, the ideal temperature conditions for storage should be between 0 to $2 \stackrel{\circ}{ } \mathrm{C}$, while the relative humidity between 90 to $98 \%$. Therefore, quite different from those found in the visited markets, whose average temperature and humidity reached $30{ }^{\circ} \mathrm{C}$ and $40 \%$, respectively, during the study period. Therefore, quite different from those found in the visited markets, whose mean temperature and humidity reached $30^{\circ} \mathrm{C}$ and $40 \%$, respectively, during the study period. It should be noted that only $14.95 \%$ of the establishments visited were duly acclimatized, and none of them contained a cold room.

According to Finger et al. (2011), leafy vegetables have organs that store an inexpressive amount of carbohydrates, and the consequent lack of energy reserve drastically reduces the storage potential. However, in the present study, fewer losses were estimated for lettuce than for underground vegetables, for example, which generally have a high carbohydrate content in the form of starch. It may be related to the efficient planning of the volume offered and at a short distance from the productive sector, usually represented by small family producers. However, it is important to note that some improvements are still needed to reduce these lettuce losses to acceptable limits, below $5 \%$.

In general, vegetables-fruit showed higher losses than the other groups, probably due to the morphophysiological aspects that increase their perishabilities, such as thin epidermis, climacteric stage, and highwater content. This induces an early ripening and senescence, withering, and wrinkling of these products. When comparing fruits and vegetables losses by city, it was observed that the two highest volumes of fruit offered occurred in Colinas $\left(93,60 \mathrm{~kg} \mathrm{week}^{-1}\right)$ and São Domingos do Maranhão $\left(83,47 \mathrm{~kg}^{\text {week }}{ }^{-1}\right)$. However, relative losses were more significant in São Bernardo (17.68\%) and Santa Quitéria (17.09\%) (Table 3). That is, only these two cities presented losses greater than $10.01 \%$, while the others had median losses.

Table 3: Postharvest losses of fruits and vegetables in the retail sector of differents microregions of Maranhão.

\begin{tabular}{llllllll}
\hline \multirow{2}{*}{ Cities } & \multirow{2}{*}{ Population } & \multirow{2}{*}{ Microregion } & \multirow{2}{*}{ N } & Fruits & \multicolumn{4}{c}{ Vegetable Crops } \\
\cline { 5 - 8 } & & & MVO & RL & MVO & RL \\
\hline Presidente Dutra & 47,567 & & 40 & 25.57 & 7.70 & 23.03 & 12.02 \\
São Domingos do Maranhão & 34,368 & \multirow{2}{*}{ Presidente Dutra } & 15 & 83.47 & 6.36 & 82.29 & 11.07 \\
Dom Pedro & 23,328 & & 15 & 72.72 & 7.02 & 64.27 & 16.52 \\
Fortuna & 15,536 & & 15 & 58.58 & 6.83 & 32.89 & 5.39 \\
\hline Colinas & 41,042 & Chapadas do Alto Itapecuru & 15 & 93.60 & 7.01 & 98.94 & 9.23 \\
\hline Santa Quitéria & 29,191 & \multirow{2}{*}{ Baixo Parnaíba Maranhense } & 03 & 17.64 & 17.09 & 15.27 & 12.60 \\
São Bernardo & 28,343 & & 04 & 21.07 & 17.68 & 18.41 & 10.80 \\
\hline
\end{tabular}

$\mathrm{N}$ : number of sampled establishments; MVO: Mean volume offered (kg week ${ }^{-1}$ ); and RL: Relative loss (\%). Population was estimated by the IBGE.

Data obtained for São Bernardo and Santa Quitéria are alarming and contradict the hypotheses of Tofanelli et al. (2009), who stated that the greater the volume traded and the perishability of the product, the greater the losses in retail. Therefore, they expose the inefficiency of the sector in conserving fruits for 
sale, even when the volume offered is smaller than other cities, with a smaller population, such as Fortuna. In contrast, Presidente Dutra and São Domingos do Maranhão, who offered the most expressive volumes, proved to be more efficient in fruits conservations. It must be highlighted that these cities have higher populations, which makes them able to consume the fresh fruits available for trading more quickly.

Concerning vegetables, five cities showed losses greater than $10.01 \%$, and only two presented mean losses, which shows greater susceptibility of these vegetables compared to fruits. Among these five cities, Dom Pedro and Santa Quitéria stood out with relative losses of $16.52 \%$ and $12.60 \%$, respectively.

The cities of Santa Quitéria and São Bernardo, located in the Baixo Parnaíba Maranhense microregion, showed high losses for fruits and vegetables. It is assumed that this result may be associated with sampling aspects of this study, but mainly with socioeconomic indicators and or the marketing scenario. According to Azevedo et al. (2016), this microregion has weak socioeconomic indicators, which could hinder investments in postharvest practices improvements. Nevertheless, it is understood that awareness is a tool without cost, and can help these traders to obtain greater profitability in commercial activity.

Likely, the postharvest losses recorded in the present study are mainly related to poorly planning of the quantity offered; inefficient conditions for packaging, storage and marketing; distance between distribution centers and the final consumer; poor conditions of the Maranhão roads; and eating habits of the population that prolong the product display time on the shelves. It is understood that some of these aspects may be corrected by processes of technical training and awareness of the current damages of losses.

\section{CONCLUSIONS}

The level of education of the traders interviewed is still low, as only $5 \%$ had completed a higher education level. However, around $60 \%$ have a high level of technical knowledge about the management and commercialization of fruit and vegetables. More than $96 \%$ of the product marketed in the seven cities sampled come from Piauí, Bahia, and Ceará, transported mainly in open trucks, without refrigeration, on paved roads. The products are stored for up to seven days in commercial establishments, among which stand out the greengroceries, as the most representative segment.

Among fruits, papaya (17.90\%), avocado (16.55\%), and guava (13.82\%) highlighted as the most lost, while for vegetables were eggplant $(24.70 \%)$, potatoes $(15.98 \%)$ and cucumber $(15.69 \%)$. The main losses cause identified are physiological disorders and mechanical damage. In the comparison of relatives losses by city, Santa Quitéria and São Bernardo are the cities with the highest rates. Thus, it is necessary to stimulate the fruits and vegetables production in Maranhão, as well as to provide better training in commercial management and good postharvest practices for these products, in order to increase the profitability of the activity.

ACKNOWLEDGMENTS: The Fundação de Amparo à Pesquisa e ao Desenvolvimento Tecnológico no Estado do Maranhão (FAPEMA), for the financial resource, Edital Universal 31/2016, process 960/17. 


\section{REFERENCES}

ABF. Anuário Brasileiro de Fruticultura. Brazilian Fruit Yearbook. Santa Cruz do Sul: Gazeta Santa Cruz, 2017.

ABH. Anuário Brasileiro de Hortaliças. Brazilian Vegetable Yearbook. Santa Cruz do Sul: Gazeta, 2017.

AGHDAM, M. S.; BODBODAK, S.. Tratamento térmico póscolheita para mitigação de lesões por resfriamento em frutas e legumes. Revista Tecnologia de alimentos e bioprocessos, Nova York, v.7, n.1, p.37-53, 2014. DOI: https://doi.org/10.1007/s11947-013-1207-4

ALMEIDA, E. I. B.; RIBEIRO, W. S.; COSTA, L. C.; LUCENA, H. H.; BARBOSA, J. A.. Levantamento de perdas em hortaliças frescas na rede varejista de Areia (PB). Revista Brasileira de Agropecuária Sustentável, Viçosa, v.2, n.1, p.53-60, 2012. DOI: https://doi.org/10.21206/rbas.v2i1.58

AMOR, A. L. M.; SILVA, R. M.; SILVA, A. A. M. R.; ARAÚJO, W C.; OLIVEIRA, A. J.; ALMEIDA, J. S.; SILVA, A. S.; ROCHA, É. V. S.; REBOUÇAS, L. T.; SILVA, I. M. M.. Perfil de manipuladores e consumidores de hortaliças provenientes de feiras livres e supermercados. Revista Baiana de Saúde Pública, Salvador, v.36, n.3, p.792-815, 2012. DOI:

https://doi.org/10.22278/2318-2660.2012.v36.n3.a556

AMORIM, D. J.; ALMEIDA, E. I. B.; FERRÃO, G. E.; PIRES, I. C. G.. Análise da qualidade e do preço de hortaliças comercializadas no mercado varejista de Chapadinha/MA. Revista Agrotrópica, Ilhéus, v.29, n.2, p.151-156, 2017. DOI: http://doi.org/10.21757/0103-3816.2017v29n2p151-156

ANTUNES, L. E. C.; FAGHERAZZI, A. F.; VIGNOLO, G. K.. Morangos tem produção crescente. Campo \& Lavoura, Anuário HF 2017, v.96, n.1, p.96-102, 2017.

AZEVEDO, J. R.; DANTAS, J. S.; FARIAS, M. F.. Qualidade de vida de famílias rurais do território Baixo Parnaíba-MA. In: AZEVEDO, J. R.. Análise sobre a política territorial no Baixo Parnaíba-MA. São Luís: EDUFMA, 2016. p.60.

BARBOSA, J. A.; RIBEIRO, W. S.; ALMEIDA, E. I. B.. Levantamento das perdas pós-colheita de frutos, hortaliças e flores no estado da Paraíba. Brasília: Kiron, 2012.

BARRETO, C. F.; SILVA, PRICILA, S.; KIRINUS, M. B. M.; SCHIAVON, C. R.; MALGARIM, M. B. M.; FACHINELLO, J. C.. Armazenamento refrigerado de pêssegos 'Maciel' de plantas conduzidas em diferentes porta-enxertos. Revista Iberoamericana de Tecnologia Postcosecha, Cidade do México, v.17, n.2, p.254-261, 2016.

CAMPOS, L. S.; SOUSA, K. A.; SILVA, T. R.. Diagnóstico das perdas pós-colheita do maracujá (Passiflora edulis sims) comercializado no mercado varejista de Palmas, TO. Biológico, São Paulo, v.77, n.2, p.21-54, 2015.

CANELLA, D S.; LOUZADA, M. L. C.; CLARO, R. M.; COSTA, J. C.; BANDONI, D. H.; LEVY, R. B.; MARTINSII, A. P. B.. Consumo de hortaliças e sua relação com os alimentos ultraprocessados no Brasil. Revista Saúde Pública, São
Paulo, v.52, n.1, p.50, 2018. Dol:

http://doi.org/10.11606/s1518-8787.2018052000111

CARVALHO, J. L.; MACHADO, W. R. B.; BISPO, L. P.; LIMA JUNIOR, P. C. R.. Perdas na comercialização de Frutas, Legumes e Verduras: os casos da banana e da cebola no Mercado Produtor de Juazeiro (BA). In: CONGRESSO BRASILEIRO DE ENGENHARIA DE PRODUÇÃO, 29. Anais. Ponta Grossa: UTFPR, 2015.

CASSETARI, L. S.. Controle genético dos teores de clorofila e carotenoides em folhas de alface. Tese (Doutorado em Fitotecnia) - Universidade Federal de Lavras, Lavras, 2015.

CASTRO, E. M. C.. Perdas na comercialização de quatro hortaliças tuberosas em supermercados de Guanhães - MG. Tese (Doutorado em Fitotecnia) - Universidade Federal de Viçosa, Viçosa, 2013.

CHITARRA, M. I. F.; CHITARRA, A. B.. Pós-colheita de frutos e hortaliças: fisiologia e manuseio. 2 ed. Lavras: UFLA, 2005.

CIA, P.; BENATO, E. A.; VALENTINI, S. R. T.; SANCHES, J.; PONZO, F. S.; FLÔRES, D.; TERRA, M. M.. Atmosfera modificada e refrigeração para conservação pós-colheita de uva 'Niagara Rosada'. Pesquisa agropecuária brasileira, Brasília, v.45, n.10, p.1058-1065, 2010. DOI: http://doi.org/10.1590/s0100-204×2010001000002

COSTA, C. C.; GUILHOTO, J. J. M.; BURNQUIST, H. L.. Impactos Socioeconômicos de Reduções nas Perdas Póscolheita de Produtos Agrícolas no Brasil. Revista de Economia e Sociologia Rural, Piracicaba, v.53, n.3, p.395408, 2015. DOI: http://doi.org/10.1590/1234-56781806$\underline{9479005303002}$

DIAS, M. A.. Logística, transporte e infraestrutura: armazenagem, operador logístico, gestão via TI, multimodal. São Paulo: Atlas, 2012.

FERREIRA, A. G. C.; FERREIRA, L. S.; FREITAS JÚNIOR, F. G. B. F.; SANTOS, M. P.; SILVA, M. S.; AGUIAR, F. I. S.; COSTA, T. V.; ALMEIDA, E. I. B.; SOUSA, W. S.; FREITAS, J. R. B.. Postharvest losses of fruits and vegetables marketed in seven municipalities of the east Mesorregion, Maranhão, Brazil. Journal of Agricultural Studies, v.8, n.3, p.335-351, 2020. DOI: https://doi.org/10.5296/jas.v8i3.16098

FINGER, F. L.; FRANÇA, C. F. M.. Pré-resfriamento e conservação de hortaliças folhosas. In: CONGRESSO BRASILEIRO DE OLERICULTURA, 51. Anais. Viçosa: ABH, 2011.

FREITAS JÚNIOR, F. G. B. F.. Uso de embalagens plásticas e revestimento comestível para conservação de goiaba, em diferentes ambientes de armazenamento. Monografia (Bacharelado em Agronomia) - Universidade Federal do Maranhão, Chapadinha, 2019.

GOTO, R.. Reflexões sobre a cadeia de frutas e hortaliças. In: ANUÁRIO ESTATÍSTICO DA AGRICULTURA BRASILEIRA. Anais. São Paulo: FNP, 2010. 
GUERRA, A. M. N.; COSTA, A. C. M.; FERREIRA, J. B. A.; TAVARES, P. R. F.; VIEIRA, T. S.; MEDEIROS, A. C.. Avaliação das principais causas de perdas pós-colheita de hortaliças comercializadas em Santarém, Pará. Revista Verde de Agroecologia e Desenvolvimento Sustentável, João Pessoa, v.12, n.1, p.34-40, 2017. DOI:

http://doi.org/10.18378/rvads.v12i1.4809

LERMEN, J. P.. Comportamento do consumidor de hortifrútis. Monografia (Bacharelado em Administração) Universidade do Vale do Taquari, Lajeado, 2017.

NASCIMENTO, S. S.; MENDES, M. S.; SOUSA, A. N. S.; ALMEIDA, E. I. B.; PIRES, I. C. G.. Panorama da comercialização e perdas pós-colheita no setor varejista de frutas frescas, em Chapadinha (MA). Agrotrópica, Ilhéus, v.31, n.2, p.159-168, 2019. DOI: http://doi.org/10.21757/0103-3816.2019v31n2p159-168

NEVES, L. C.. Manual pós-colheita da fruticultura brasileira. Londrina: EDUEL, 2016.

OLIVEIRA, E. N. A.; SANTOS, D. C.. Tecnologia e processamento de frutos e hortaliças. Natal: IFRN, 2015.

RIBEIRO, W. S.; BARBOSA, J. A.; CARNEIRO, G. G.; LUCENA, H. H.; ALMEIDA, E. I. B.. Controle do fungo penducular do abacaxi Pérola. Revista Brasileira de Produtos Agroindustriais, Campina Grande, v.13, n.1, p.1-6, 2011. DOI: http://doi.org/10.15871/1517-8595/rbpa.v13n1p1-6

SENA, E. O. A.; COUTO, H. G. S. A.; PAIXÃO, A. R. C.; SILVEIRA, M. P. C.; JÚNIOR, L. F. G. O.; CARNELOSSI, M. A. G.. Utilização de biofilme comestível na conservação pós-colheita de pimentão verde (Capsicum annuum L.), Scientia Plena, Aracaju, v.12, n.8, p.1-9, 2016. DOI:

http://dx.doi.org/10.14808/sci.plena.2016.080201

MELO, C. C. R.. Perdas pós-colheita de bananas 'Prata-anã' na propriedade rural e no mercado varejista: um estudo de caso. Tese (Doutorado em Fitotecnia) - Universidade Federal de Viçosa, Viçosa, 2013.

SILVA, L. R.; ALMEIDA, E. I. B.; FERREIRA, L. S.; FIGUEIRINHA, K. T.; FERREIRA, A. G. C.; SOUSA, W. S.. Estimativa e causas de perdas pós-colheita de frutas frescas na Microrregião de Chapadinha, Maranhão, Brasil. Revista Agro@mbiente, Boa Vista, v.12, n.4, p.288-299, 2018. DOI:

http://doi.org/10.18227/1982-8470ragro.v12i4.5223
SILVA, M. A. C. R.. Diversidade cultural na diversidade alimentar: comida na Tríplice Fronteira. Dissertação (Mestrado em Rede Nacional para o Ensino de Ciências Ambientais) - Universidade Federal do Amazonas, Manaus, 2018.

SILVA, M. D. C.. Monitoramento e identificação de doenças e uso de embalagens plásticas na conservação do tomate. Monografia (Bacharelado em Agronomia) - Universidade Federal do Maranhão, Chapadinha, 2019.

SOARES, A. G.; JÚNIOR, M. F.. Perdas de frutas e hortaliças relacionadas às etapas de colheita, transporte $e$ armazenamento. In: ZARO, M.. Desperdício de alimentos: velhos hábitos, novos desafios. Caxias do Sul: Educs, 2018. p.21-37.

SOUSA, A. N. S.; ALMEIDA, E. I. B.; NASCIMENTO, S. S.; MENDES, M. S.; SOUSA, W. S.; MELO, P. A. F. R.. Perdas póscolheita de hortaliças no mercado varejista de Chapadinha, Maranhão, Brasil. Revista Agrotrópica, Ilhéus, v.30, n.2, p.127-134, 2018. DOI: http://doi.org/10.21757/01033816.2018v30n2p127-134

TOFANELLI, M. B. D.; FERNANDES, M. S.; MARTINS FILHO, O. B.; CARRIJO, N. S.. Avaliação das perdas de frutas e hortaliças no mercado varejista de Mineiros/GO: um estudo de caso. Scientia Agraria, Curitiba, v.10, n.4, p.331-336, 2009. DOI: http://doi.org/10.5380/rsa.v10i4.14857

TOMM, T. F. R.; ALMEIDA, E. I. B.; FIGUEIRINHA, K. T.; FERREIRA, L. S.; AMORIM, D. J.; GONDIM, M. M. S.. Procedência e perdas pós-colheita de hortaliças na microrregião de Chapadinha, Maranhão, Brasil. Revista Agro@mbiente, Boa Vista, v.12, n.3, p.200-212, 2018. DOI: http://doi.org/10.18227/1982-8470ragro.v12i3.5026

TOMM, T. F. R.; SOUSA, A. N. S.; NASCIMENTO, S. S.; MENDES, M. S.; ALMEIDA, E. I. B.; GONDIM, M. M. S.. Cenário da comercialização e estimativa de perdas póscolheita de frutas temperadas em Chapadinha (MA). In: FARIAS, M. F.. Tópicos em produção agrícola no Leste Maranhense. São Luís: EDUFMA, 2016. p.232-240.

VIEITES, R. L.; DAIUTO, E. R.; FUMES. J. F. F.. Capacidade antioxidante e qualidade pós colheita de abacate 'Fuerte'. Revista Brasileira de Fruticultura, Jaboticabal, v.34, n.2, p.336-348, 2012. DOI: https://doi.org/10.1590/s0100$\underline{2945201200020000}$

A CBPC - Companhia Brasileira de Produção Científica (CNPJ: 11.221.422/0001-03) detém os direitos materiais desta publicação. Os direitos referem-se à publicação do trabalho em qualquer parte do mundo, incluindo os direitos às renovações, expansões e disseminações da contribuição, bem como outros direitos subsidiários. Todos os trabalhos publicados eletronicamente poderão posteriormente ser publicados em coletâneas impressas sob coordenação da Sustenere Publishing, da Companhia Brasileira de Produção Científica e seus parceiros autorizados. Os (as) autores (as) preservam os direitos autorais, mas não têm permissão para a publicação da contribuição em outro meio, impresso ou digital, em português ou em tradução. 